\title{
SISTEM PENYIMPANAN ENERGI PANAS KONTAK LANGSUNG MENGGUNAKAN LARUTAN $\mathrm{Na}_{2} \mathrm{HPO}_{4} \cdot 12 \mathrm{H}_{2} \mathrm{O}$
}

\author{
Panut Mulyono, I Made Bendiyasa, Dita Budi Wibawa, dan Suryo Birowo \\ Jurusan Teknik Kimia, Fakultas Teknik, \\ Universitas Gadjah Mada \\ J1. Grafika No.2, Yogyakarta 55281, Telp. (0274) 902171, Fax. (0274) 902170 \\ E-mail: pmulyono@chemeng.ugm.ac.id
}

Naskah diterima 5 Agustus 2005, dinilai 10 Agustus 2005, dan disetujui 11 Nopember 2005

\begin{abstract}
Abstrak
Penelitian ini mempelajari sistem penyimpanan energi panas kontak langsung inenggunakan larutan $\mathrm{Na}_{2} \mathrm{HPO}_{4} \cdot 12 \mathrm{H}_{2} \mathrm{O}$ sebagai media penyimpan energi. Kerosin panas digunakan sebagai fluida alir sumber energi panas. Masalah yang dipelajari pada penelitian ini adalah nilai koefisien perpindahan panas volumetris dan kapasitas penyimpanan panasnya. Percobaan dilakukan dengan menggelembungkan kerosin panas dari dasar kolom yang berisi larutan $\mathrm{Na}_{2} \mathrm{HPO}_{i} \cdot 12 \mathrm{H}_{2} \mathrm{O}$. Kolom yang digunakan dibuat dari gelas dengan ketebalan $3 \mathrm{~mm}$, mempunyai diameter dalam $7 \mathrm{~cm}$, dan tinggi kolomnva adalah $100 \mathrm{~cm}$. Parameter yang dipelajari dalam penelitian ini adalah pengaruh kecepatan volumetris kerosin dan pengaruh diameter gelembung kerosin terhadap nilai koefisien perpindahan panas volumetris dan terhadap kecepatan penyimpanan panasmya. Hasil penelitian menunjukkan bahwa nilai koefisien perpindahan panas volumetris sangat dipengaruhi oleh kecepatan volumetris kerosin sehingga kecepatan penyimpanan panasnya juga sangat dipengaruhi oleh kecepatan volumetris kerosin. Pengaruh ukuran diameter gelembung terhadap nilai koefisien perpindahan panas volumetris dan terhadap kecepatan penyimpanan panasnya sangat kecil sehingga dapat diabaikan.
\end{abstract}

Kata Kunci: Sistem Penyimpanan Energi Panas, Kontak Langsung, Larutan $\mathrm{Na}_{2} \mathrm{HPO}_{4} \cdot 12 \mathrm{H}_{2} \mathrm{O}$.

\begin{abstract}
The volumetric coefficient of heat transfer and the energy storage capacity in a direct contact thermal energy storage system using $\mathrm{Na}_{2} \mathrm{HPO}_{4} \cdot 12 \mathrm{H}_{2} \mathrm{O}$ solution as thermal energy storage medium have been investigated. Hot kerosene was used as a heat transfer fluid. The experiments were carried out by, bubbling hot kerosene from the bottom of a column containing $\mathrm{Na}_{2} \mathrm{HPO}_{4} 12 \mathrm{H}_{2} \mathrm{O}$ solution. The column used in this experiment was made from glass of $3 \mathrm{~mm}$ in thickness with an inside diameter of $7 \mathrm{~cm}$ and a height of $100 \mathrm{~cm}$. The effects of kerosene flow rate and kerosene bubble diameter on the volumetric coefficient of heat transfer and the storing rate of energy were studied. It was found that the volumetric coefficient of heat transfer was strongly affected by the flow rate of the kerosene and that the effect of the kerosene flow rate on the storing rate of energy was relatively high, while that of the effect of the bubble diameter was neglectable.
\end{abstract}

Keywords: Direct Contact, Thermal Energy Storage System, $\mathrm{Na}_{2} \mathrm{HPO}_{4} \cdot 12 \mathrm{H}_{2} \mathrm{O}$ Solution 


\section{Pendahuluan}

Penyimpanan energi panas sering kali harus dilakukan, karena pada saat suatu sumber mengeluarkan energi tersebut, kebutuhan untuk menggunakannya terjadi pada waktu lain. Sebagai contoh, energi panas matahari yang dipancarkan pada siang hari dapat disimpan untuk digunakan pada malam hari, misalnya untuk memanaskan air.

Garam terhidrasi merupakan bahan yang baik sebagai penyimpan energi panas untuk suhu yang tidak terlalu tinggi karena kemampuan penyimpanan panas bahan ini cukup tinggi dan harganya relatif murah dibandingkan dengan bahan lain. Hal yang tidak menguntungkan dari penggunaan garam terhidrasi untuk penyimpanan energi panas adalah terjadinya pelelehan yang tidak merata sehingga menyebabkan pemisahan fase selama siklus penyimpanan dan pemanfaatan panas yang berulang-ulang. Pendinginan di bawah titik beku juga merupakan masalah pada penggunaan garam terhidrasi untuk media penyimpan energi panas. Dua masalah ini telah didiskusikan oleh Telkes (1952), Etherington (1957), Biswas (1977), dan Farid dan Yacoub (1989).

Etherington (1957) adalah peneliti yang pertama-tama memperkenalkan ide untuk menggunakan perpindahan panas kontak langsung antara zat yang tidak dapat bercampur sebagai sumber panas dan larutan garam terhidrasi. Minyak ringan yang digunakan sebagai fluida sumber panas digelembungkan dari dasar larutan sodium phosphate decahydrate. Panas dipindahkan dari gelembung minyak ke larutan garam tanpa melewati dinding logam. Garamgaram terhidrasi yang telah dipelajari oleh para peneliti antara lain adalah $\mathrm{Na}_{2} \mathrm{SO}_{4} \cdot 10 \mathrm{H}_{2} \mathrm{O}$, $\mathrm{Na}_{2} \mathrm{HPO}_{4} \cdot 12 \mathrm{H}_{2} \mathrm{O}, \mathrm{CaCl}_{2} \cdot 6 \mathrm{H}_{2} \mathrm{O}$ dan sodium asetat (Etherington, 1957 dan Fouda dkk, 1980). Farid dan Khalaf (1994) mempelajari unjuk kerja sistem penyimpan energi panas kontak langsung menggunakan dua jenis larutan garam terhidrasi yaitu $\mathrm{Na}_{2} \mathrm{CO}_{3} \cdot 10 \mathrm{H}_{2} \mathrm{O}$ dan $\mathrm{Na}_{2} \mathrm{~S}_{2} \mathrm{O}_{3} \cdot 5 \mathrm{H}_{2} \mathrm{O}$. Pemilihan kedua jenis garam tersebut adalah berdasarkan pada perbedaan suhu kristalisasi diantara keduanya. Pada penelitian-penelitian di atas, tidak dipelajari secara intensif tentang koefisien perpindahan panas volumetris antara fluida sumber panas dengan larutan garamnya dengan membuat model matematis yang dapat digunakan untuk mengevaluasi koefisien perpindahan panas volumetris tersebut.

Kiatsiriroat dkk (2000) mempelajari unjuk kerja sistem penyimpanan energi panas kontak langsung menggunakan larutan sodium thiosulphate pentahydrate dan heat tranșfer oil digunakan sebagai fluida sumber panas. Dalam analisisnya, mereka menggunakan lumped model. Model tersebut digunakan untuk mengevaluasi suhu minyak keluar kolom, suhu larutan penyimpan panas, dan fraksi padatan yang tersisa dalam larutan. Mulyono (2004) juga telah mempelajari sistem penyimpanan energi panas kontak langsung menggunakan larutan $\mathrm{Na}_{2} \mathrm{CO}_{3} \cdot 10 \mathrm{H}_{2} \mathrm{O}$ dengan analisis menggunakan lumped model.

Pada penelitian ini dikembangkan sebuah model matematis untuk sistem penyimpanan energi panas kontak langsung yang berbeda dengan lumped model. Model ini dibuat berdasarkan neraca panas pada sistem itu dan digunakan untuk mengevaluasi nilai koefisien perpindahan panas volumetrisnya. Peubah-peubah yang berpengaruh terhadap nilai koefisien perpindahan panas volumetris tersebut dipelajari, lalu disajikan dalam bentuk persamaan bilangan tidak berdimensi. Persamaan ini dapat dijadikan pedoman untuk perancangan sistem penyimpan energi panas kontak langsung berskala industri. Larutan $\mathrm{Na}_{2} \mathrm{HPO}_{4} \cdot 12 \mathrm{H}_{2} \mathrm{O}$ digunakan sebagai media penyimpan energi itu dengan pertimbangan bahwa kapasitas penyimpanan energi per satuan beratnya cukup besar dibandingkan dengan zat lain. Kerosin panas digunakan sebagai model sumber energi yang energinya dipindahkan ke larutan $\mathrm{Na}_{2} \mathrm{HPO}_{4} \cdot 12 \mathrm{H}_{2} \mathrm{O}$.

\section{Fundamental}

Sistem penyimpanan energi panas kontak langsung, secara skematis ditunjukkan pada Gambar 1. Pada prinsipnya, tluida pembawa energi panas (di sini digunakan kerosin) digelembungkan menembus larutan $\mathrm{Na}_{2} \mathrm{HPO}_{4} \cdot 12 \mathrm{H}_{2} \mathrm{O}$. Gelembung-gelembung kerosin memberikan panasnya ke larutan sehingga suhu larutan naik dan suhu gelembung kerosin makin ke atas makin kecil. Kerosin yang sudah mengalir sampai ke bagian atas larutan, lalu didaur ulang ke bejana pemanas kerosin. Di sini dibuat model matematis untuk merumuskan perpindahan panas dari gelembung kerosin ke larutan $\mathrm{Na}_{2} \mathrm{HPO}_{4} \cdot 12 \mathrm{H}_{2} \mathrm{O}$.

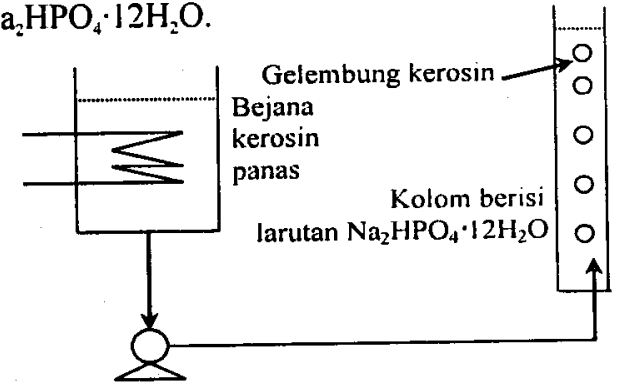

Gambar 1. Skema Sistem Penyimpanan Energi Panas Kontak Langsung 
Dalam menyusun model matematis yang digunakan untuk menghitung nilai koefisien perpindahan panas volumetris antara gelembung kerosin dengan larutan $\mathrm{Na}_{2} \mathrm{HPO}_{4} \cdot 12 \mathrm{H}_{2} \mathrm{O}$ diambil beberapa asumsi seperti yang tercantum pada Tabel 1 .

Tabel 1. Asumsi-asumsi yang Digunakan untuk Menyusun Model Matematis

\begin{tabular}{|c|l|}
\hline No. & \multicolumn{1}{|c|}{ Asumsi } \\
\hline 1 & $\begin{array}{l}\text { Aliran gelembung-gelembung Kerosin } \\
\text { bersifat plug flow, sedangkan larutan } \\
\mathrm{Na}_{2} \mathrm{HPO}_{4} .12 \mathrm{H}_{2} \mathrm{O} \text { di dalam kolom bersifat } \\
\text { well mixed. }\end{array}$ \\
\hline 2 & $\begin{array}{l}\text { Suhu kerosin }\left(T_{k}\right) \text { seragam untuk suatu } \\
\text { ketinggian tertentu. }\end{array}$ \\
\hline 3 & $\begin{array}{l}\text { Gradien suhu baik suhu gelembung } \\
\text { kerosin maupun suhu larutan } \\
\text { Na } \mathrm{HPO}_{4} .12 \mathrm{H}_{2} \mathrm{O} \text { arah radial diabaikan. }\end{array}$ \\
\hline 4 & $\begin{array}{l}\text { Sifat-sifat fisis kerosin dan larutan } \\
\mathrm{Na}_{2} \mathrm{HPO}_{4} \cdot 12 \mathrm{H}_{2} \mathrm{O} \text { tetap terhadap perubahan } \\
\text { Suhu. }\end{array}$ \\
\hline
\end{tabular}

Dengan memperhatikan asumsi-asumsi pada Tabel 1 di atas, dapat disusun neraca panas pada elemen volume kolom yang berisi larutan $\mathrm{Na}_{2} \mathrm{HPO}_{4} \cdot 12 \mathrm{H}_{2} \mathrm{O}$. Dari neraca panas pada fase minyak dalam elemen volume diperoleh persamaan sebagai berikut:

$$
\begin{aligned}
& F_{v, k} \rho_{k} C_{p, k} \frac{d T_{k}}{d z}+U_{v} A \varepsilon\left(T_{k}-T_{l}\right)= \\
& -A \varepsilon \rho_{k} C_{p, k} \frac{d T_{k}}{d t}
\end{aligned}
$$

Neraca panas pada fasa larutan $\mathrm{Na}_{2} \mathrm{HPO}_{4} \cdot 12 \mathrm{H}_{2} \mathrm{O}$ dalam elemen volume diperoleh Persamaan (2) berikut.

$$
\begin{aligned}
& U_{v} A \varepsilon\left(T_{k}-T_{l}\right)-U_{w} \pi D_{l}\left(T_{d}-T_{\infty}\right)= \\
& {\left[A_{g} \rho_{g} C_{p, g}+A \rho_{l} C_{p, l}(1-\varepsilon)\right] \frac{d T_{l}}{d t}}
\end{aligned}
$$

$U_{v}$ pada Persamaan (1) dan (2) merupakan koefisien perpindahan panas volumetris berdasarkan volume larutan $\mathrm{Na}_{2} \mathrm{HPO}_{4} \cdot 12 \mathrm{H}_{2} \mathrm{O} . U_{w}$ pada Persamaan (2) adalah koefisien perpindahan panas konveksi antara dinding tabung dengan udara, nilainya ditentukan dengan cara mengisi kolom dengan larutan $\mathrm{Na}_{2} \mathrm{HPO}_{4} \cdot 12 \mathrm{H}_{2} \mathrm{O}$ dan membiarkannya menjadi dingin tanpa digelembungkan kerosin. Penurunan suhu larutan sebagai fungsi waktu dicatat. Dari neraca panas untuk keadaan ini diperoleh persamaan sebagai berikut (Mulyono, 2004):

$$
\ln \frac{T_{l}-T_{\infty}}{T_{l, 0}-T_{\infty}}=-\frac{U_{w} \pi D_{l} H t}{\rho_{l} C_{p, l} V_{l}+M_{t} C_{p, g}}
$$

Keadaan batas untuk Persamaan (1) dan Persamaan (2) adalah:

$$
\begin{array}{ll}
T_{1}(\mathrm{z}, 0) & =T_{1} \text { mula-mula } \\
T_{1}(\mathrm{z}, \mathrm{t}) & =\text { tertentu } \\
T_{k}(0, \mathrm{t}) & =T_{k} \text { masuk kolom, tertentu } \\
T_{k}(\mathrm{z}, 0) & =T_{k}(0, \mathrm{t}) \\
T_{k}(\mathrm{~L}, \mathrm{t}) & =\text { tertentu }
\end{array}
$$

Jadi, suhu larutan $\left(T_{t}\right)$ hanya merupakan fungsi waktu sedangkan $T_{k}$ merupakan fungsi waktu dan posisi. Dengan menyelesaikan Persamaan (1) dan Persamaan (2) dan mencocokkan $T$, dan $T_{k}$ terhitung dengan $T_{\text {, dan }} T_{k}$ hasil percobaan, maka akan diperoleh nilai $U_{\text {v }}$ untuk sistem tersebut.

Pada penelitian ini, jari-jari gelembung kerosin yang mengalir menembus larutan $\mathrm{Na}_{2} \mathrm{HPO}_{4} \cdot 12 \mathrm{H}_{2} \mathrm{O}$ dihitung dengan rumus empiris yang dikembangkan oleh Farid dan Khalaf (1994) sebagai berikut:

$$
R_{g}=0,0038-0,0013\left(\frac{F_{v, k}}{A_{s p}}\right)
$$

Jumlah energi yang tersimpan di larutan $\mathrm{Na}_{2} \mathrm{HPO}_{4} \cdot 12 \mathrm{H}_{2} \mathrm{O}$ sebagai fungsi waktu dihitung dengan Persamaan (5) berikut:

$$
Q_{l}(t)=M_{l} C_{p, l}\left[T_{l}(t)-T_{l, t}\right]
$$

Hubungan antara koefisien perpindahan panas volumetris dengan peubah-peubah yang mempengaruhinya dapat diformulasikan dalam bentuk persamaan bilangan tidak berdimensi menggunakan analisis dimensi sebagai berikut:

$\frac{U_{r} d_{g}{ }^{2}}{k_{k}}=$

$\alpha \cdot \operatorname{Pr}_{k}{ }^{\prime \prime} \operatorname{Pr}_{l}{ }^{c 2} \operatorname{Re}_{k}{ }^{c 3}\left(\frac{\rho_{k}}{\rho_{l}}\right)^{c^{\prime} 4}\left(\frac{k_{l}}{k_{k}}\right)^{(' s}\left(\frac{\mu_{l}}{\mu_{k}}\right)^{C \cdot 6}$

$\alpha, \mathrm{Cl}, \mathrm{C} 2, \mathrm{C} 3, \mathrm{C} 4, \mathrm{C} 5$, dan C6 merupakan tetapantetapan dan dicari dengan metode regresi polinomial multidimensi dengan menggunakan input dari data hasil percobaan.

\section{Metodologi}

Larutan garam yang digunakan sebagai media penyimpan panas adalah larutan $\mathrm{Na}_{2} \mathrm{HPO}_{4} \cdot 12 \mathrm{H}_{2} \mathrm{O}$ dalam akuades dengan konsentrasi $30 \%$ berat. Dalam penelitian ini. kerosin digunakan sebagai fluida pembawa panas. 
Rangkaian alat yang digunakan untuk percobaan laboratorium ditunjukkan pada Gambar 2. Tabung dibuat dari gelas dengan diameter dalam $7 \mathrm{~cm}$, tebal $3 \mathrm{~mm}$, dan tinggi $100 \mathrm{~cm}$. Sparger atau distributor yang digunakan ada tiga macam. Salah satunya dibuat dari seng dengan diameter lubang $3 \mathrm{~mm}$. Dua sparger lainnya dibuat dari gelas masing-masing dengan diameter lubang 1 $\mathrm{mm}$ dan $5 \mathrm{~mm}$. Jumlah lubang pada sparger tergantung pada diameter lubangnya. Dalam percobaan, diameter lubang merupakan variabel yang diubah-ubah. Bejana pemanas kerosin dibuat dari ember dengan volume 13 liter yang dilengkapi dengan isolator panas. Pemanas listrik 1000 Watt digunakan pada penelitian ini. Agar suhu kerosin dalam bejana selalu seragam, maka bejana dilengkapi dengan pengaduk listrik. Bejana tabung gelas diperlukan untuk memisahkan kerosin dengan larutan yang terbawa aliran kerosin dari puncak kolom perpindahan panas. Larutan yang terpisahkan dari bejana ini dikumpulkan dalam penampung larutan berupa ember plastik.

Pada rangkaian alat percobaan dipasang 5 buah termometer yang digunakan sebagai alat pengukur suhu. Sebuah termometer dipasang di arus kerosin masuk dasar kolom untuk mengukur suhu kerosin masuk dasar kolom, 3 buah termometer dipasang pada kolom untuk mengukur suhu larutan dan sebuah lagi dipasang pada puncak kolom untuk mengukur suhu kerosin keluar kolom. Jarak antara dasar kolom dengan termometer paling bawah yang dipasang pada kolom adalah $23 \mathrm{~cm}$, jarak antara termometer paling bawah dengan termometer yang di tengah adalah $22 \mathrm{~cm}$, dan jarak antara termometer yang di tengah dengan termometer di atasnya juga $22 \mathrm{~cm}$.

Untuk mengevaluasi koefisien perpindahan panas konveksi antara dinding kolom bagian luar dengan udara lingkungan, dilakukan dengan jalan mengisi kolom dengan larutan $\mathrm{Na}_{2} \mathrm{HPO}_{4} \cdot 12 \mathrm{H}_{2} \mathrm{O}$ dalam akuades dengan konsentrasi $30 \%$ berat pada suhu awal tertentu, tanpa dilakukan pengadukan, dan penurunan suhu larutan sebagai fungsi waktu dicatat. Data yang diperoleh digunakan untuk mengevaluasi koefisien perpindahan panas konveksi antara dinding kolom bagian luar dengan udara lingkungan menggunakan Persamaan (3).

Sebelum alat-alat percobaan dirangkai seperti pada Gambar 2, terlebih dahulu dilakukan peneraan terhadap rotameter dan termometer yang digunakan. Setelah itu, alat penelitian disusun seperti Gambar 2, tabung gelas diisi dengan larutan $\mathrm{Na}_{2} \mathrm{HPO}_{4} \cdot 12 \mathrm{H}_{2} \mathrm{O} 30 \%$ berat dan kerosin ditempatkan pada tangki kerosin. Sebelum dilakukan percobaan, terlebih dahulu diadakan pengecekan mengenai kemungkinan kebocoran

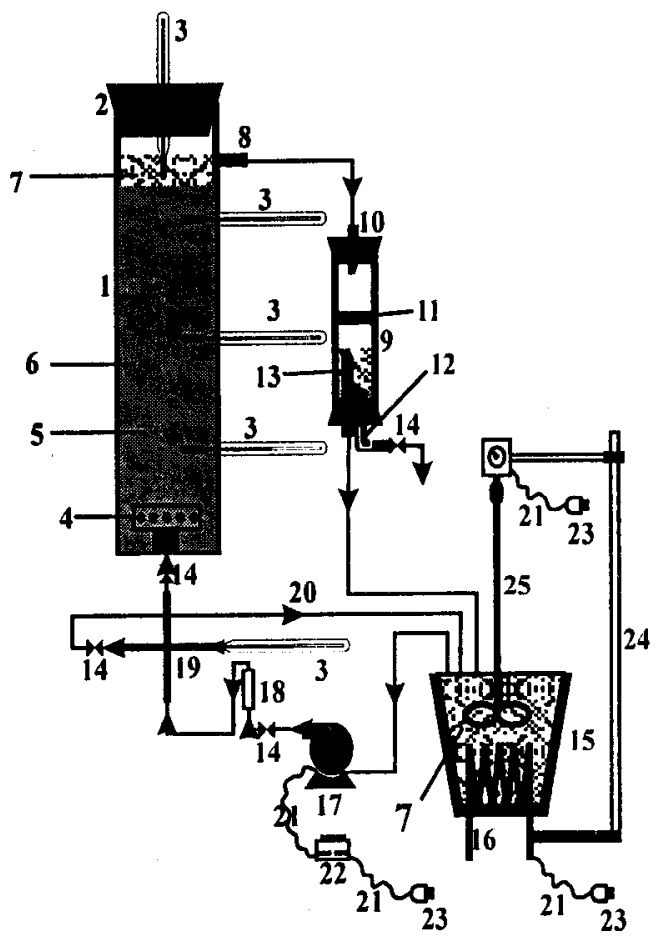

Keterangan :

1. Kolom perpindahan panas

2. Sumbat karet

3. Termometer alkohol

4. Sparger

5. Gelembung kerosin

6. Larutan garam

7. Kerosin

8. Saluran Pembuangan kerosin

9. Tabung penyaring Larutan garam

10. Pipa kaca pemasukan kerosin

12. Pipa kaca pembuangan

13. Pipa kaca pengeluaran kerosin

14. Valve(keran)

15. Tangki penyimpanan kerosin

16. Kuil pemanas

17.Pompa air

18. Flowmeter

19.Pipa kaca bercabang 4

20. Selang saluran sirkulasi kerosin

21.Kabel listrik

22. Regulator

23. Steker

24.Statip dan klem

25. Motor pengaduk

\section{Gambar 2. Rangkaian Alat Percobaan}

yang ada. Percobaan dilakukan sebagai berikut, mula-mula kerosin dipanaskan pada tangki dengan pemanas listrik dan dikontrol pada suhu tertentu. Setelah suhu yang diinginkan dicapai, kerosin panas ini dialirkan ke dalam kolom melalui sparger sehingga gelembung-gelembung kerosin naik dan kontak langsung dengan larutan $\mathrm{Na}_{2} \mathrm{HPO}_{4} \cdot 12 \mathrm{H}_{2} \mathrm{O}$ dan memindahkan sebagian panas yang dibawanya. Laju aliran kerosin diatur dengan kran dan diukur dengan rotameter. Suhu kerosin masuk dan keluar kolom diukur dengan termometer dan dicatat sebagai fungsi waktu. Suhu larutan garam dalam kolom pada 3 buah posisi juga diukur dengan termometer dan hasilnya dicatat sebagai fungsi waktu. Percobaan 
dihentikan bila perubahan suhu kerosin keluar kolom sebagai fungsi waktu sudah cukup kecil. Data yang diperoleh digunakan untuk menghitung koefisien perpindahan panas volumetris antara kerosin dan larutan $\mathrm{Na}_{2} \mathrm{HPO}_{4} \cdot 12 \mathrm{H}_{2} \mathrm{O}$ dengan Persamaan (1) dan Persamaan (2). Data yang diperoleh adalah data untuk menentukan koefisien perpindahan panas konveksi antara dinding luar kolom dengan lingkungan dan data untuk menentukan koefisien perpindahan panas volumetris antara kerosin dengan larutan $\mathrm{Na}_{2} \mathrm{HPO}_{4} \cdot 12 \mathrm{H}_{2} \mathrm{O}$.

Koefisien perpindahan panas konveksi antara dinding luar kolom dengan lingkungan dievaluasi dengan menyelesaikan Persamaan (3) secara numeris dan mencoba nilai $U_{\text {r }}$ pada persamaan itu sehingga waktu untuk mencapai suhu tertentu dari larutan hasil penyelesaian Persamaan (3) cocok dengan data percobaan. Nilai $U_{\text {w }}$ yang benar adalah yang memberikan sum of square of error (SSE) minimum antara hasil perhitungan dengan data percobaan. SSE didefinisikan sebagai $\left(t_{\text {hit }}-t_{\text {datal }}\right)^{2}$. Dengan $t$ adalah waktu yang diperlukan untuk mencapai suhu tertentu dari larutan.

Evaluasi koefisien perpindahan panas volumetris $\left(U_{v}\right)$ antara kerosin dengan larutan $\mathrm{Na}_{2} \mathrm{HPO}_{4} \cdot 12 \mathrm{H}_{2} \mathrm{O}$ dilakukan dengan mencoba nilai $U_{v}$ tertentu pada Persamaan (1) dan Persamaan (2) dan menyelesaikan persamaan-persamaan itu secara numeris serta membandingkan nilai $T_{k, o}$ dan $T_{1}$ hasil perhitungan dengan $T_{k . .}$ dan $T_{1}$ hasil percobaan laboratorium. $T_{k \omega}$ adalah suhu kerosin keluar kolom sebagai fungsi waktu dan $T$, adalah suhu larutan sebagai fungsi waktu/setiap saat. $\left(T_{1}\right.$ setiap saat seragam/tidak merupakan fungsi posisi). Nilai $U_{v}$ yang benar adalah yang memberikan SSE minimum antara suhu terhitung dengan suhu hasil percobaan. Minimasi nilai SSE dilakukan dengan metode Golden Section. Untuk hasil percobaan pada kondisi tertentu, maka

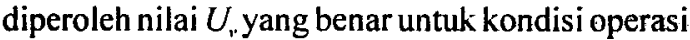
itu.

\section{Hasil dan Pembahasan}

Koefisien perpindahan panas $\mathrm{U}_{\text {w }}$ dihitung menggunakan Persamaan (3) dari data percobaan hubungan antara penurunan suhu larutan $\mathrm{Na}_{2} \mathrm{HPO}_{4} \cdot 12 \mathrm{H}_{2} \mathrm{O}$ dengan waktu. Dari perhitungan diperoleh nilai $U_{*} 0,1847 \mathrm{~kW} / \mathrm{m}^{20} \mathrm{C}$.

Gambar 3 menunjukkan data eksperimen dan hasil perhitungan untuk suhu kerosin keluar kolom dan data eksperimen serta hasil perhitungan untuk suhu larutan sebagai fungsi waktu untuk suhu kerosin masuk kolom dijaga tetap $60^{\circ} \mathrm{C}$ dengan kecepatan aliran $9,04 \mathrm{~cm} /$ detik dan diameter gelembung 7,93 $\mathrm{mm}$. Pada Gambar 3 dapat dilihat bahwa pada awal proses, suhu kerosin keluar kolom cukup rendah kemudian suhu itu naik dengan bertambahnya waktu. Pada awal proses, suhu larutan masih rendah sehingga kecepatan perpindahan panas dari kerosin ke larutan masih besar. Hal ini ditunjukkan pula dengan naiknya suhu larutan sebagai fungsi waktu karena menerima panas dari kerosin. Perbedaan antara suhu kerosin dengan suhu larutan yang cukup besar di awal proses menyebabkan suhu kerosin keluar kolom cukup rendah di awal proses dan suhu tersebut naik dengan bertambahnya waktu. Gambar 3 menunjukkan bahwa beda antara suhu kerosin keluar kolom dan suhu larutan data eksperimen cocok dengan suhu hasil perhitungan. Galat rerata perbedaan antara suhu larutan data eksperimen dengan suhu larutan hasil perhitungan adalah $2,43 \%$.

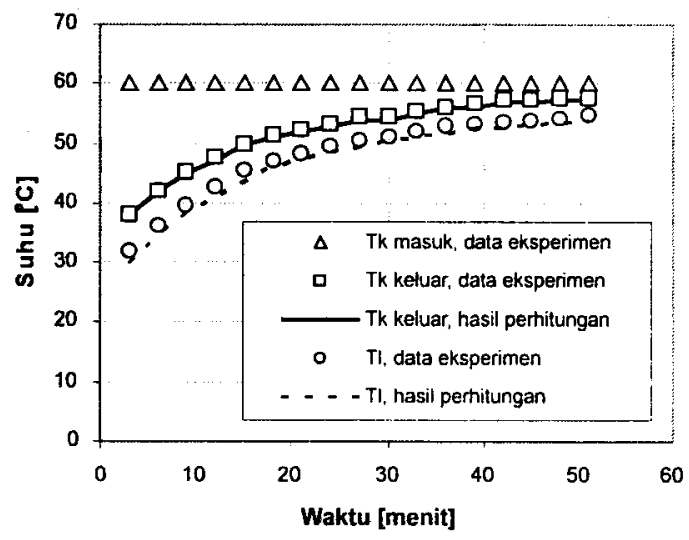

Gambar 3. Suhu Kerosin $\left(T_{k}\right)$ dan Suhu Larutan $\left(T_{s}\right)$ sebagai Fungsi Waktu untuk Suhu Kerosin Masuk 60 $0^{\circ}$, Kecepatan Aliran Kerosin $9,04 \mathrm{~cm}^{3} /$ detik dan Diameter Gelembung 7,93 m m

Hasil perhitungan koefisien perpindahan panas volumetris $\left(U_{v}\right)$ untuk kondisi percobaan di atas (suhu kerosin masuk $60^{\circ} \mathrm{C}$, kecepatan aliran kerosin $9,04 \mathrm{~cm}^{3} /$ detik dan diameter gelembung $7,93 \mathrm{~mm}$ ) ditunjukkan pada Gambar 4. Seperti yang ditunjukkan pada Gambar 4, nilai $U_{v}$, pada awal proses adalah $1,1 \mathrm{~kW} / \mathrm{m}^{3}$ " $\mathrm{C}$, lebih besar dari nilai $U_{v}$ di akhir proses, yaitu $0,33 \mathrm{~kW} / \mathrm{m}^{3}{ }^{3} \mathrm{C}$. Penurunan nilai $U_{\nu}$ ini diperkirakan karena adanya perubahan sifat-sifat fisis larutan dengan naiknya suhu. Gambar 5 menunjukkan penurunan nilai $U_{\text {. }}$. terhadap kenaikan suhu larutan untuk percobaan dengan kondisi seperti yang diterangkan di atas. 


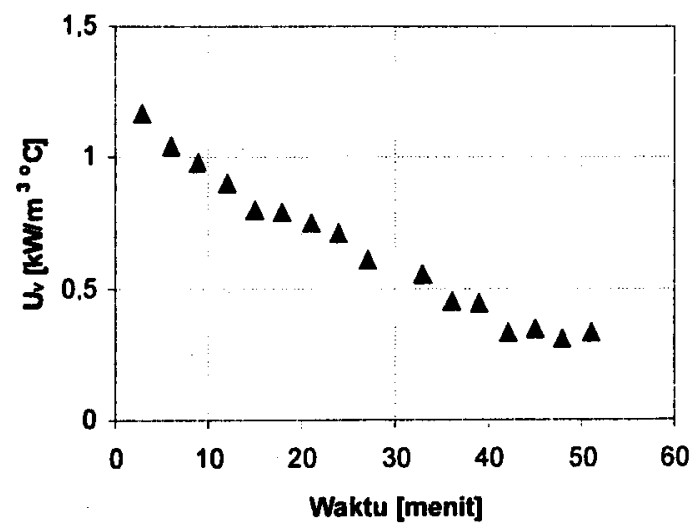

Gambar 4. Nilai Uv sebagai Fungsi Waktu untuk Suhu Kerosin Masuk 60"C, Kecepatan Aliran Kerosin $9,04 \mathrm{~cm}^{3} /$ detik dan Diameter Gelembung 7,93 mm

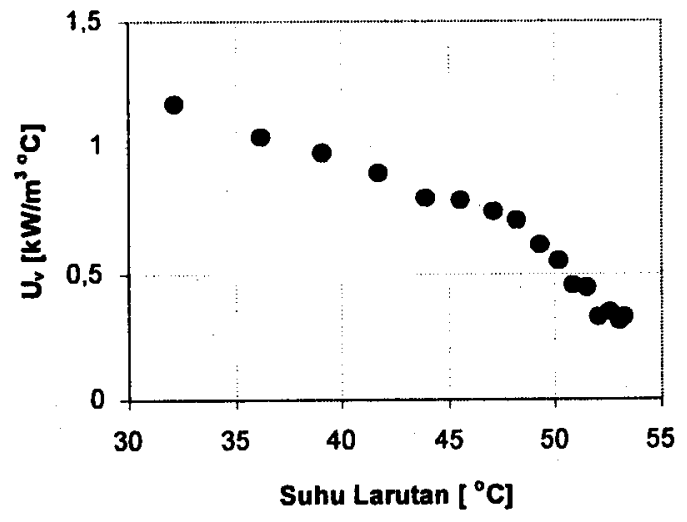

Gambar 5. Penurunan Nilai $U_{\text {, }}$ sebagai Fungsi Suhu Larutan untuk Suhu Kerosin Masuk $60^{\prime \prime} \mathrm{C}$, Kecepatan aliran kerosin $9,04 \mathrm{~cm}^{3} /$ detik dan Diameter Gelembung 7,93 mm

Pengaruh kecepatan volumetrik kerosin masuk kolom terhadap kecepatan naiknya suhu larutan ditunjukkan pada Gambar 6 untuk suhu kerosin masuk 60 " $\mathrm{C}$ dan diameter gelembung 7,93 mn. Gambar 6 menunjukkan bahwa kecepatan naiknya suhu larutan bertambah besar dengan naiknya kecepatan volumetrik kerosin. Pada percobaan dengan kecepatan volumetrik kerosin $9,04 \mathrm{~cm}^{3} /$ detik, suhu larutan setelah proses berjalan 21 menit adalah $48^{\circ} \mathrm{C}$ sedangkan dengan kecepatan volumetrik kerosin 16,62 $\mathrm{cm}^{3} /$ detik $56{ }^{\circ} \mathrm{C}$, berarti terjadi kenaikan sebesar $16,7 \%$. Naiknya kecepatan volumetrik kerosin memperkecil ukuran diameter gelembung kerosin seperti yang diformulasikan dengan Persamaan (4). Berkurangnya diameter gelembung untuk massa yang sama memperbesar nilai $U_{r,}$, dengan demikian maka kecepatan perpindahan panas dari kerosin ke larutan menjadi makin besar.

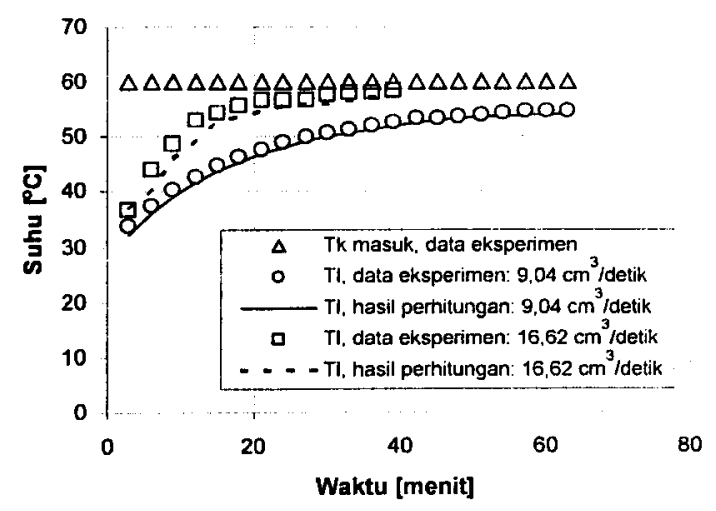

Gambar 6. Kecepatan Kenaikan Suhu Larutan sebagai Fungsi dari Kecepatan Volumetris Kerosin (Suhu Kerosin Masuk 60"C dan Diameter Gelembung 7,93 m m)

Gambar 7 menunjukkan pengaruh kecepatan volumetris kerosin terhadap nilai $U_{\text {v }}$ untuk percobaan yang dilakukan dengan subu kerosin masuk kolom $70^{\circ} \mathrm{C}$ dan diameter gelembung 6,69 mm. Dapat dilihat pada Gambar 7 bahwa untuk suhu kerosin masuk dan diameter gelembung yang sama, makin besar kecepatan volumetris kerosin menyebabkan naiknya nilai $U_{v}$. Pada percobaan dengan kecepatan volumetrik kerosin $9,04 \mathrm{~cm}^{3} /$ detik, nilai $U_{v}$ setelah proses berjalan 12 menit adalah $1,27 \mathrm{~kW} / \mathrm{m}^{3}$."C sedangkan dengan kecepatan volumetrik kerosin $16,62 \mathrm{~cm}^{3} /$ detik adalah $1,81 \mathrm{~kW} / \mathrm{m}^{\circ} .{ }^{\circ} \mathrm{C}$, yang berarti terjadi kenaikan sebesar $42,5 \%$. Naiknya kecepatan volumetrik kerosin memperkecil ukuran diameter gelembung kerosin seperti yang diformulasikan dengan Persamaan (4). Berkurangnya diameter gelembung untuk massa yang sama memperbesar nilai $U_{v}$.

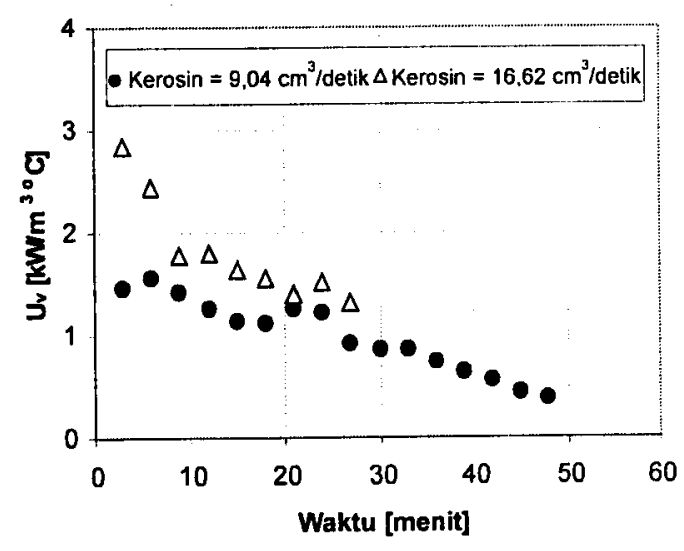

Gambar 7. Pengaruh Kecepatan Volumetris Kerosin terhadap Nilai $U_{v}$ untuk Percobaan dengan Suhu Kerosin Masuk Kolom 70"C dan Diameter Gelembung 6,69 $\mathrm{mm}$ 
Jumlah energi yang tersimpan di dalam larutan pada setiap saat dalam proses penyimpanan dihitung dengan Persamaan (5). Hasil perhitungan untuk percobaan dengan kecepatan volumetris kerosin $9,04 \mathrm{~cm}^{3} /$ detik dan $16,62 \mathrm{~cm}^{3} /$ detik (suhu kerosin masuk $60^{\circ} \mathrm{C}$ dan diameter sparger 6,69 $\mathrm{mm}$ ) ditunjukkan pada Gambar 8. Seperti dapat dilihat pada Gambar 8 bahwa kapasitas penyimpanan energi pada larutan pada waktu yang sama naik dengan naiknya kecepatan volumetrik kerosin. Seperti ditunjukkan pada Gambar 6 dan Gambar 7 bahwa kenaikan kecepatan volumetrik kerosin memperbesar nilai $U_{v}$ sehingga memperbesar perpindahan panas dari kerosin ke larutan.

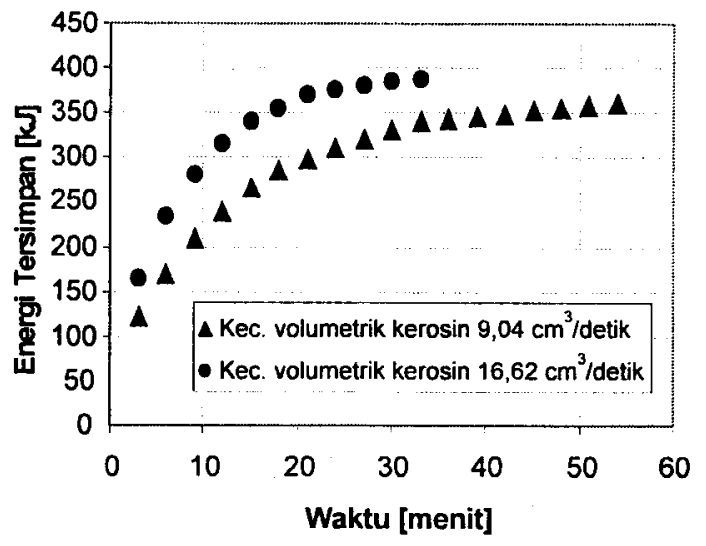

Gambar 8. Jumlah Energi Tersimpan di Larutan sebagai Fungsi Waktu untuk Kecepatan Volumetris Kerosin yang Berbeda (Suhu Kerosin Masuk $60^{\circ} \mathrm{C}$ dan Diameter Gelembung 6,69 mm)

Untuk mempelajari pengaruh ukuran gelembung terhadap kecepatan kenaikan suhu larutan, nilai koefisien perpindahan panas volumetris, dan kecepatan penyimpanan panas dalam larutan, maka dilakukan eksperimen dengan suhu kerosin masuk $60^{\circ} \mathrm{C}$ dan kecepatan volumetrik kerosin $9,04 \mathrm{~cm}^{3} /$ detik. Diameter gelembung kerosin divariasikan dengan cara memasang sparger dengan diameter lubang yang berbeda, yaitu 3 dan $5 \mathrm{~mm}$. Gambar 9 menunjukkan kecepatan kenaikan suhu larutan baik data eksperimen maupun hasil perhitungan untuk percobaan dengan diameter gelembung yang berbeda (suhu kerosin masuk $60^{\circ} \mathrm{C}$ dan kecepatan volumetris kerosin $9,04 \mathrm{~cm}^{3} /$ detik). Dapat dilihat pada Gambar 9 bahwa kecepatan naiknya suhu larutan sedikit bertambah dengan dikecilkannya ukuran gelembung. Pada eksperimen dengan ukuran gelembung $6,69 \mathrm{~mm}$, suhu larutan setelah proses berjalan 15 menit adalah $48^{\circ} \mathrm{C}$ sedangkan dengan ukuran gelembung $7,93 \mathrm{~mm}$ adalah $45,4^{\circ} \mathrm{C}$, berarti terjadi kenaikan sebesar $5,7 \%$ untuk pengecilan ukuran gelembung dari 7,92 mm menjadi $6,69 \mathrm{~mm}$. Berkurangnya ukuran gelembung untuk kecepatan volumetris kerosin yang sama memperbesar nilai $U_{v}$, dengan demikian maka kecepatan perpindahan panas dari kerosin ke larutan menjadi makin besar.

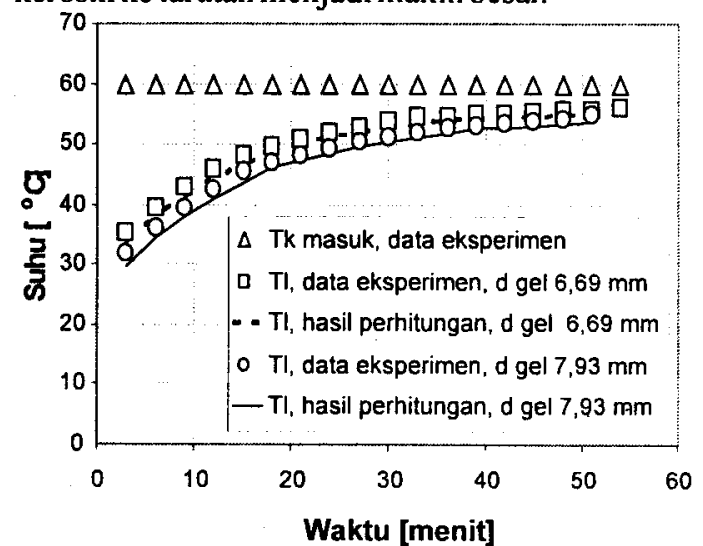

Gambar 9. Kecepatan Kenaikan Suhu Larutan untuk Diameter Gelembung yang Berbeda (suhu Kerosin masuk $60^{\circ} \mathrm{C}$ dan Kecepatan Volumetris Kerosin $9,04 \mathrm{~cm}^{3} /$ detik)

Gambar 10 menunjukkan perubahan nilai $U_{v}$ untuk diameter gelembung yang berbeda (suhu kerosin masuk $60^{\circ} \mathrm{C}$ dan kecepatan volumetris kerosin $9,04 \mathrm{~cm}^{3} /$ detik). Dapat dilihat pada Gambar 10 bahwa untuk suhu kerosin masuk dan kecepatan volumetris yang sama, makin kecil diameter gelembung menyebabkan naiknya nilai $U_{v}$. Pada percobaan dengan diameter gelembung $6,69 \mathrm{~mm}$, nilai $U_{\nu}$ setelah proses berjalan 15 menit adalah $0,94 \mathrm{~kW} / \mathrm{m}^{3} .{ }^{\circ} \mathrm{C}$ sedangkan dengan diamater gelembung $7,93 \mathrm{~mm}$ adalah $0,79 \mathrm{~kW} / \mathrm{m}^{3}$." $\mathrm{C}$, yang

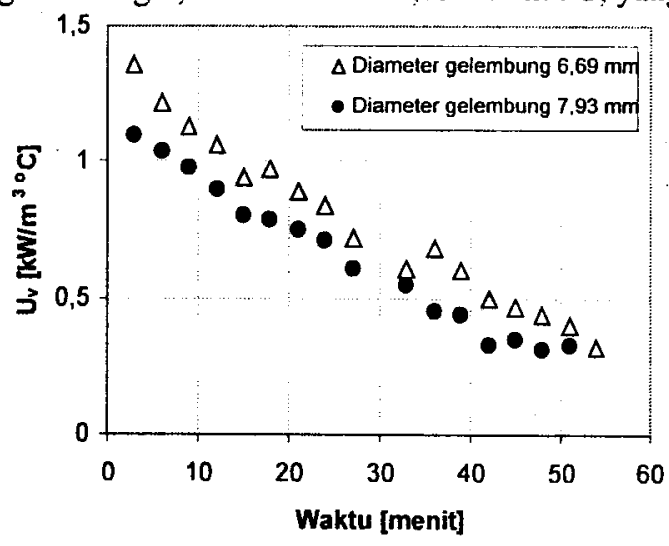

Gambar 10. Pengaruh Diameter Gelembung terhadap Nilai $U_{\text {, untuk Percobaan dengan }}$ Suhu Kerosin Masuk Kolom 60"C dan Kecepatan Volumetris Kerosin $9,04 \mathrm{~cm}^{3} /$ detik 
berarti terjadi kenaikan sebesar $18,99 \%$ dengan turunnya diameter gelembung dari $7,93 \mathrm{~mm}$ menjadi $6,69 \mathrm{~mm}$. Berkurangnya diameter gelembung untuk kecepatan volumetris kerosin yang sama berarti memperbesar luas perpindahan panas per satuan volumenya sehingga memperbesar nilai $U_{r}$.

Hasil perhitungan jumlah energi tersimpan di larutan untuk percobaan dengan diameter gelembung $6,69 \mathrm{~mm}$ dan $7,93 \mathrm{~mm}$ (suhu kerosin masuk kolom $60^{\circ} \mathrm{C}$ dan kecepatan volumetris kerosin $9,04 \mathrm{~cm}^{3} /$ detik) ditunjukkan pada Gambar 11. Seperti dapat dilihat pada Gambar 11 bahwa kapasitas penyimpanan energi pada larutan pada waktu yang sama naik dengan berkurangnya diameter gelembung untuk suhu kerosin masuk kolom dan kecepatan volumetris yang sama. Namun demikian kenaikannya sangat kecil. Hal ini sesuai dengan data yang disajikan pada Gambar 9 dan Gambar 10 bahwa berkurangnya diameter gelembung hanya sedikit meningkatkan kecepatan kenaikan suhu larutan dan sedikit memperbesar nilai $U_{v}$.

Hubungan antara nilai koefisien perpindahan panas volumetris $\left(U_{v}\right)$ dengan peubah-peubah yang mempengaruhinya diformulasikan dalam bentuk persamaan bilangan tidak berdimensi seperti yang ditunjukkan pada persamaan (7):

$\frac{U_{1} \cdot d_{g}{ }^{2}}{k_{k}}=$

$5,04 \operatorname{Pr}_{k}{ }^{3,52} \operatorname{Pr}_{l}^{5,05} \operatorname{Re}_{k}^{1,00}\left(\frac{\rho_{k}}{\rho_{l}}\right)^{0,97}\left(\frac{k_{l}}{k_{k}}\right)^{0,20}\left(\frac{\mu_{l}}{\mu_{k}}\right)^{0,78}$

dengan kesalahan rerata sebesar $26,53 \%$.

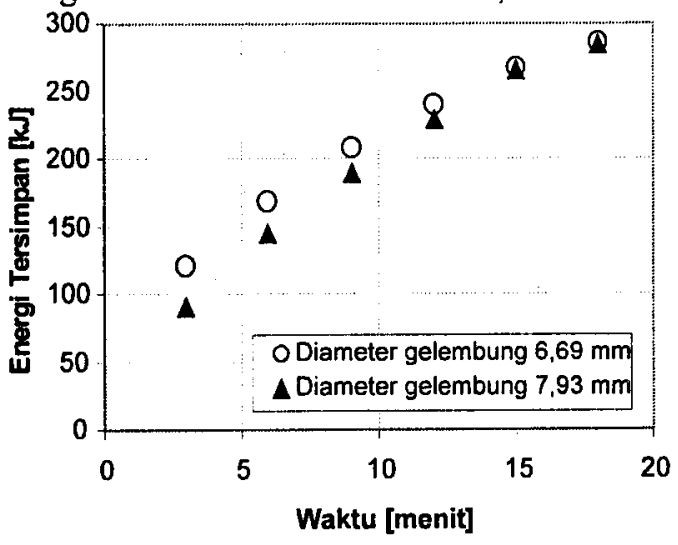

Gambar 11. Jumlah Energi Tersimpan di Larutan sebagai Fungsi Waktu untuk Diameter Gelembung yang Berbeda (Suhu Kerosin Masuk $60^{\circ} \mathrm{C}$ dan Kecepatan Volumetris Kerosin 9,04 $\mathrm{cm}^{3} /$ detik)

\section{Kesimpulan}

Dari penelitian ini dapat ditarik kesimpulan bahwa pengaruh perubahan kecepatan volumetris kerosin terhadap nilai koefisien perpindahan panas volumetris lebih besar dari pada pengaruh perubahan diameter gelembung. Jika ditinjau dari pengaruh perubahan kecepatan volumetris kerosin, didapatkan bahwa perubahan kecepatan volumetris kerosin berpengaruh relatif besar terhadap kecepatan penyimpanan panas pada larutan, namun sebaliknya pengaruh perubahan diameter gelembung sangat kecil.

Kenaikan kecepatan volumetrik kerosin dari $9,04 \mathrm{~cm}^{3} /$ detik menjadi $16,62 \mathrm{~cm}^{3} /$ detik untuk percobaan dengan suhu kerosin masuk kolom $70^{\prime \prime} \mathrm{C}$ dan diameter gelembung $6,69 \mathrm{~mm}$, pada 12 menit pertama menaikkan nilai $U_{v}$ dari $1,27 \mathrm{~kW} / \mathrm{m}^{3}$." $\mathrm{C}$ menjadi $1,81 \mathrm{~kW} / \mathrm{m}^{3} .{ }^{\circ} \mathrm{C}$ atau terjadi kenaikan sebesar $42,5 \%$.

Pengurangan diameter gelembung dari $7,93 \mathrm{~mm}$ menjadi $6,69 \mathrm{~mm}$, pada 15 menit pertama meningkatkan nilai $U_{r}$ dari $0,79 \mathrm{~kW} / \mathrm{m}^{3}$."C menjadi $0,94 \mathrm{~kW} / \mathrm{m}^{3}$."C atau terjadi kenaikan sebesar $18,99 \%$.

Hubungan antara nilai koefisien perpindahan panas volumetris $\left(U_{v}\right)$ dengan peubah-peubah yang mempengaruhinya adalah:

$$
\begin{aligned}
& \frac{U_{v} d_{g}{ }^{2}}{k_{k}}= \\
& 5,04 \operatorname{Pr}_{k}^{3,52} \operatorname{Pr}_{l}^{5,05} \operatorname{Re}_{k}^{1,00}\left(\frac{\rho_{k}}{\rho_{l}}\right)^{0,97}\left(\frac{k_{l}}{k_{k}}\right)^{0,20}\left(\frac{\mu_{l}}{\mu_{k}}\right)^{10,78}
\end{aligned}
$$

dengan kesalahan relatif rerata $26,53 \%$.

\section{Ucapan Terimakasih}

Penulis mengucapkan terimakasih yang sebesar-besarnya kepada Fakultas Teknik UGM atas biaya yang diberikan untuk pelaksanaan penelitian ini melalui Dana Masyarakat FT UGM tahun 2005 dengan Nomor Kontrak UGM/TK/1645/M/05/01. Penulis juga mengucapkan terimakasih kepada semua pihak yang telah membantu kelancaran penelitian ini.

\section{Daftar Notasi}

$A \quad=$ luas penampang lint ang kolom, $\mathrm{m}^{2}$

$A_{g} \quad=$ luas berdasarkan ketebalan dinding kolom, $\mathrm{m}^{2}$

$A_{s p} \quad=$ luas total lubang sparger, $\mathrm{m}^{2}$

$C_{p, g}=$ kapasitas panas dinding gelas, $\mathrm{kJ} /(\mathrm{kg} . \mathrm{K})$

$C_{p, l}=$ kapasitas panas larutan, $\mathrm{kJ} /(\mathrm{kg} . \mathrm{K})$

$C_{\rho, k}=$ kapasitas panas kerosin, $\mathrm{kJ} /(\mathrm{kg} . \mathrm{K})$ 


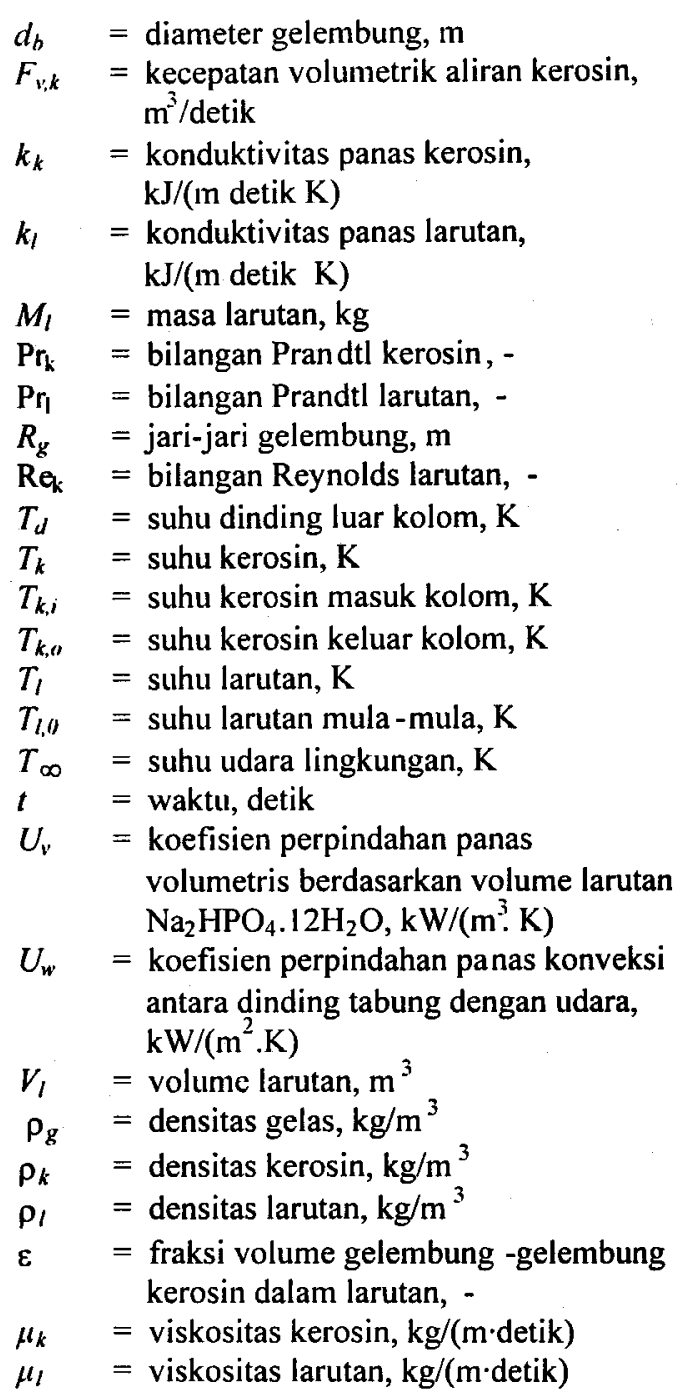

\section{Daftar Pustaka}

[1] Biswas, D.R., (1977), "Thermal Energy Storage Using Sodium Sulphate Decahydrate and Water", Solar Energy, 19, 99-100

[2] Etherington, T.L., (1957), “A dynamic Heat Storage System", Heating Piping and Air Conditioning Journal, Dec., 147-151

[3] Farid, M.M. and Yacoub, K., (1989), "Performance of Direct Contact Latent Heat Storage Unit", Solar Energy, 43(4), 237-252

[4] Farid, M.M. and Khalaf, A.N., (1994), "Performance of Direct Contact Latent Heat Storage Units With Two Hydrate Salts", Solar Energy, 52(2), 179-189

[5] Fouda, A.E., Despault, G.J.G., Taylor, J.B., Capes, C.E., (1984), "Solar Storage System Using Salt Hydrate Latent Heat and Direct Contact Heat Exchanger-II", Solar Energy, 32(1), 57-65.
[6] Kiatsiriroat, T., Tiansuwan, J., Suparos, T., and $\mathrm{Na}$ Thalang, K., (2000), "Performance Analysis of a Direct Contact Thermal Energy Storage Solidification", Renewable Energy, 20, 195-206

[7] Mulyono, P., (2004), "Direct Contact Thermal Energy Storage System Using $\mathrm{Na}_{2} \mathrm{CO}_{3} \cdot 10 \mathrm{H}_{2} \mathrm{O}$ Solution", Energy, 29, 2573-2583

[8] Telkes, M., (1952), "Nucleation of the Supersaturated Inorganic Salt Solution", Ind. Eng. Chem, 44(6), 1308 